\title{
Public transport usage among university students: what to expect based on customer satisfaction survey (CSS) analysis
}

\author{
Thiago Carvalho dos Reis Silveira ${ }^{1}$, Cezar Augusto Romano ${ }^{2}$, Tatiana Maria Cecy Gadda ${ }^{3}$ \\ ${ }^{1}$ Universidade Tecnológica Federal do Paraná. Curitiba, PR, Brasil, thiagocarvalhoreis@gmail.com \\ 2Universidade Tecnológica Federal do Paraná. Curitiba, PR, Brasil, caromano@utfpr.edu.br \\ 3Universidade Tecnológica Federal do Paraná. Curitiba, PR, Brasil, tatianagadda@utfpr.edu.br
}

\section{Recebido:}

8 de agosto de 2018

Aceito para publicação:

23 de fevereiro de 2020

Publicado:

31 de agosto de 2020

Editor de área:

Sara Ferreira

\section{Keywords:}

Public Transport.

Customer Satisfaction Survey (CSS).

User Perception.

Relative Attribute Importance.

Market Segmentation.

\section{Palavras-chaves:}

Transporte Público.

Pesquisa de Satisfação do

Consumidor.

Percepção do Usuário.

Importância Relativa.

Segmentação de Mercado.

DOI:10.14295/transportes.v28i3.1797

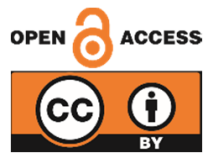

\begin{abstract}
Customer Satisfaction Surveys (CSS) are valuable tools for both public management and operating companies. It provides useful information to understand public transport users' needs, to define more effective goals, and to make more assertive investments. In the literature, the combination of market segmentation and the comparison between satisfaction and relative importance data have been rarely assessed. This study investigates the tendency for public transport continuous adoption among undergraduate students from Curitiba (Brazil) through usage habits, perceived satisfaction, relative attribute importance and GAP analysis. Overall, the results do not show an intention from the studied group to keep using this mode into the future. However, if properly motivated, students are more likely to become agents of change and could positively affect behavioral intentions toward public transport.
\end{abstract}

\section{RESUMO}

Pesquisas de Satisfação do Consumidor são ferramentas valiosas tanto para gestores públicos quanto para empresas de operação. Estas fornecem informações úteis para a compreensão das necessidades dos usuários de transporte público, para a definição de objetivos mais efetivos e para fazer investimentos mais assertivos. Na literatura, a combinação de segmentação de mercado e a comparação entre satisfação e importância relativa foi poucas vezes estudada. Este estudo investiga a tendência de adoção contínua do transporte público entre alunos universitários de Curitiba por meio de hábitos de consumo, satisfação, importância relativa dos fatores componentes e análise de GAP. De modo geral, os resultados não indicam uma intenção do grupo estudado em continuar usando este modal de transporte. No entanto, se motivados corretamente, estudantes podem se tornar mais facilmente agentes de mudança e podem afetar positivamente as intenções comportamentais em relação ao transporte público.

\section{INTRODUCTION}

In developing countries, a strong correlation is found between increasing motorization rates, income inequality and income growth (Kutzbach, 2009). This scenario leads to unsustainable congestion volumes, increasing traffic accident rates and major environmental and social impacts (Filipović et al., 2009; Gössling, 2013). In addition, bus average speed is usually reduced providing an additional incentive to perform a modal switch (Kutzbach, 2009), thus creating a vicious cycle and aggravating mobility problems. 
Increasing road capacity is a frequent, but unfeasible solution to accommodate the escalating trend on car ownership since cities are bound by financial and geographical constraints (Ercan et al., 2017). Thereby, adoption of active and public transport on a larger scale is usually linked to a shift in mindset. In this way, urban infrastructure development should be thought as to reduce economic, social and environmental impacts of extreme car dependency (Litman, 1999; Onat et al., 2016).

Sustainable development could be promoted by offering a wider range of travel options and more effective land use (Litman, 1999) or even by creating more compact communities and so reducing trip generation rates and average trip lengths (Ercan et al., 2017). Also, cooperative behaviors should be built through individual involvement on community decisions toward a sustainable environment (Litman, 1999; Van, Choocharukul and Fujii, 2014; Javid et al., 2016). Likewise, the application of soft transport policy measures, such as personalised travel planning, public transport marketing and travel awareness campaigns, have shown a positive effect on reducing car usage (Möser and Bamberg, 2008; Friman, Larhult and Gärling, 2013).

As to increase public transportation ridership, public authorities should also concentrate on adjusting its systems to passengers' needs, once loyalty is strongly associated with overall satisfaction (Lai and Chen, 2011; van Lierop and El-Geneidy, 2016). Consequently, it is essential to have knowledge of which service attributes have a greater impact on perceived quality (dell'Olio, Ibeas and Cecín, 2010; de Oña et al., 2016; Guirao, García-Pastor and López-Lambas, 2016), thus developing effective policies (Bordagaray et al., 2014; Abenoza, Cats and Susilo, 2017).

This paper focuses on investigating the tendency for continuous public transport adoption among undergraduate students in the long term. As highlighted by Mouwen (2015), it is more efficient to segregate the population and apply resources into a few manageable groups that are likely to have a change in behavior, whilst improvements would still impact positively the overall population (Bordagaray et al., 2014). To this end we applied a customer satisfaction survey (CSS) encompassing habits, satisfaction at attribute and overall levels, relative attribute importance and gap analysis between perceived and expected quality of service. Our work adds to the literature since few studies so far have analysed and compared importance and satisfaction data for a specific market segment.

\section{HIGHLIGHTS OF CUSTOMER SATISFACTION THEORY}

Satisfaction is believed to have positive impacts on both behavioral intentions (de Oña et al., 2016) and loyalty (van Lierop and El-Geneidy, 2016). Therefore, it is a strong indicator of whether a customer will continue to use a service (Zeithaml, Berry and Parasuraman, 1996). Additionally, it is influenced by perceived value, related to the discrepancy between benefits and costs, and service quality, an abstract concept related to the comparison between expected and delivered service (Parasuraman, Zeithaml and Berry, 1985; Widianti et al., 2015).

As to improve public transport mode-share, transit managers should understand what makes a customer satisfied. The answers should be applied to increase the system attractiveness and motivate long term usage (van Lierop and El-Geneidy, 2016) and loyalty behaviors, such as spread of positive word-of-mouth and willingly reuse (Lai and Chen, 2011), while discouraging car dependency (Fu and Juan, 2017).

Customer Satisfaction Surveys (CSS) are the most disseminated tool for gathering data concerning perceived performance satisfaction and attribute relative importance (de Oña and 
de Oña, 2015). Together, attribute-performance and attribute-importance help transit managers visualize a global scenario for passengers' customer evaluation (Wang, Feng and Hsieh, 2010), thus, providing useful information to define more effective goals and more profitable and assertive investments (Mouwen, 2015). Additionally, once users' needs and preferences are heterogeneous, it is necessary to understand the variety of behaviors to create more adaptable strategies (Yaya et al., 2015; de Oña et al., 2016).

Service attributes are usually selected based on a combination of methods, such as extensive literature research, focus groups, pilot users survey, and statistical tests (de Oña and de Oña, 2015). Research has proven that model predictive value increases if attributes were chosen accordingly to context (Carrillat, Jaramillo and Mulki, 2007). Given the existence of an extensive number of attributes, they are usually gathered into smaller groups called dimensions. However, there is no consensus on their nature (Morton, Caulfield and Anable, 2016). Parasuraman, Zeithaml and Berry (1985) initially proposed 10 different dimensions, which vary on a continuum from easy to difficult to measure. Through factor and reliability analysis, these dimensions were reduced into 5 , leading to the first service quality evaluation procedure: the SERVQUAL methodology (Parasuman, Zeithaml and Berry, 1988).

In transportation research, service frequency, reliability, travel time, comfort and cleanliness, information availability, staff behavior, and fare are usually considered (Dell'Olio, Ibeas and Cecin, 2011; Lai and Chen, 2011; Guirao, García-Pastor and López-Lambas, 2016) and have also been combined into several different dimensions. For example, the Transportation Research Board classify them into availability, easiness to access the public transport system, comfort and convenience factors, likeness of a potential user to become a frequent one (TRB, 2013). Given the complex, fuzzy and abstract nature of service quality, many other attempts to illustrate it can be found in the literature (e.g. Eboli and Mazzulla, 2008; Lai and Chen, 2011; Yaya et al., 2015; Mahmoud and Hine, 2016).

There are two approaches for estimating relative importance of service attributes: Stated and Derived Importance (de Oña and de Oña, 2015). Stated Importance procedures rely on directly asking users for the attribute importance, usually through psychosomatic scales (Dell'Olio, Ibeas and Cecin, 2011). It is a more intuitive method but that has several week points: it increases survey length, which can reduce response rate and accuracy, and it might also fail to differentiate mean importance ratings, once respondents tend to rate attributes at the top levels of the scale, thus yielding factors that have little influence in customer satisfaction as relevant (de Oña and de Oña, 2015). Nonetheless, it is most used by operation companies due to its simplicity (Guirao, García-Pastor and López-Lambas, 2016).

Relative importance can also be directly derived from Customer Satisfaction Survey data, without asking users about how they see attribute-importance (de Oña and de Oña, 2015). Statistical and mathematical models are mostly applied by researchers on service quality studies, such as bivariate Pearson correlations (Figler et al., 2011), Multiple Linear Regression (Guirao, García-Pastor and López-Lambas, 2016), Discriminant Analysis (Aksoy, Atilgan and Akinci, 2003), Ordered Logit (Tyrinopoulos and Antoniou, 2008; Dell'Olio, Ibeas and Cecin, 2011), Decision Trees (de Oña et al., 2016), Structural Equation Model (SEM) (Lai and Chen, 2011; de Oña et al., 2013), or mixed procedures (del Castillo and Benitez, 2013; Celik, Aydin and Gumus, 2014). 


\section{THE CASE STUDY: CURITIBA'S PUBLIC TRANSPORTATION SYSTEM}

Curitiba's transit-oriented development was born from a 1965 master plan. In later years, it would become an international reference in sustainable urban development and the Bus Rapid Transit (BRT) model would be exported to over 150 cities around the globe. Currently, the intended and unintended positive co-benefits from combining mixed and dense land-use and public transport are still noticeable throughout the city (Doll and Oliveira, 2017). Nonetheless, following a national trend, ridership within the system has been decreasing (NTU, 2017) leading to financial unbalance and general cuts in investments. On the other hand, car ownership has been increasing and stands as the highest vehicle/habitant ratio among Brazil's State capitals.

This study aims to understand whether undergraduate students, which represent about $10 \%$ of Curitiba's population, would continue to adopt public transportation on the long term given the current conditions. A questionnaire was applied online through the broadcast mailing systems of three major local universities. It was divided into 4 sections: sociodemographic characteristics, reasons for public transportation adoption, service attribute and, overall satisfaction and stated attribute importance.

12 reasons were selected from the literature (Duarte et al., 2016; Machado-León, de Oña and de Oña, 2016; Gurrutxaga et al., 2017; Xia et al., 2017) to investigate the nature of the factors leading this group to use the public transport. Principal Component Analysis and Pearson Product-Moment Matrix were applied to better understand data covariance structure.

Likewise, 17 service attributes were chosen for both customer satisfaction and relative importance evaluation (Eboli and Mazzulla, 2008; Filipović et al., 2009; Lai and Chen, 2011; Rojo et al., 2013; Bordagaray et al., 2014; Mouwen, 2015; Yaya et al., 2015; Zitrický, Gašparík and Pečený, 2015; Guirao, García-Pastor and López-Lambas, 2016; Mahmoud and Hine, 2016), which were: Fare, Safety and Security, Crowding Conditions, Vehicle Interior Conditions, Transit Connectivity, Service Frequency, Application of Sustainable Technologies, Bus Stop Infrastructure, Fleet Conservation, Travel Time, Road Conservation, Reliability, Information Service, Accessibility, Staff Behavior, Exclusive Bus Lanes Availability and Fare Integration.

Satisfaction and Stated Importance were evaluated through a 5-point Likert Scale for 17 different positive statements. In both cases, Factor, Item Reliability and Discriminant Analysis were employed to recognize common trends among the sample. In the Discriminant Analysis, heterogeneity was assessed through several sociodemographic and usage descriptive variables, including the effects of Negative Social Safety Experiences (NSSEs), related to encounters with theft and robbery, on satisfaction and relative importance. Finally, a GAP Analysis was assessed to evaluate the difference between mean satisfaction and importance results.

\section{RESULTS AND DISCUSSIONS}

\subsection{Descriptive analysis and public transportation usage}

The survey received 562 responses from which 544 were drawn as valid. It fulfilled the sampling guidelines set by Bartlett, Kotrlik and Higgins (2001) to ensure generalized results at a 5\% sample error level, since 384 answers were required for a population of about 178 thousand people. On average, the sample age mean was of 22 (s.d. 3.4) years old and followed the gender distribution published in the 2010 Brazilian census $-52.9 \%$ female and $47.1 \%$ male. 
Nearly half of the respondents (48.5\%), earns less than USD 1,000/month, followed by $36.6 \%$ ranging between USD 1,001 - 2,585/month.

Our analysis of the undergraduate students' habits shows that $93 \%$ of the sample use public transport for educational purposes, followed by leisure activities (60\%) and commute trips (41.7\%). Additionally, we found a tendency for leisure and shopping trips to be more pronounced among people with high income, while for the ones with lower income, commute and health-related trips are more common. While, in general, respondents use the public transport for up to 2 purposes (52\%), the lower income group shows a higher dependency on this mode: $34.5 \%$ use public transportation as the main mode for four or more trip purposes.

The system is used mostly during mornings (39\%) and afternoons (39.8\%). It also has more people riding it twice a day (61.8\%), than once a day (25.7\%). Predominantly, the sample is composed by frequent users, since $70.2 \%$ use it from 5 to 7 times a week. Only $13.1 \%$ use it less than twice a week.

Curitiba's public transportation system is composed by 7 distinct bus-line categories, which are easily identified by specific colors reflecting its planning based on the nexus land use, transportation, and road system. For example, among the most frequent choices in the sample it is possible to identify BRT lines (79\%) by the red color, feeder lines (48.7\%) by yellow, and direct lines (41.2\%) by grey. To make it even more coherent different lines run on different road hierarchies associated with specific population densities. As a result, BRT lines, which serve high-density axis, represent from $44 \%$ to $84 \%$ of ridership in each corridor.

Furthermore, $72.2 \%$ use 2 or more bus lines to complete their usual routes, which might imply in lower travel time satisfaction due to relatively longer transfer time. $75.6 \%$ reported finding overcrowded conditions at least three times a week from which $45.6 \%$ face it daily. As expected, this situation is more frequent during peak hours (early mornings and late afternoons) and in the lines with more ridership: BRT, feeder, and direct lines.

In a multiple answer question, respondents were presented with 12 possible reasons for their current adoption of public transportation. The results were: "I do not have a car" (70.2\%), "It's my only alternative" (55.5\%), "I do not have a driver's license" (36.8\%), price (25.2\%), traffic conditions (17.6\%), lack of parking spaces (15.1\%), system speed (14.3\%), environmental awareness (12.9\%), other factors (7.2\%), service frequency (6.6\%), impossibility of using the car at the moment (5.7\%) and comfort (0.7\%). To interpret the variance structure of the data, a Principal Component Analysis (PCA) was performed.

PCA showed that the first 4 linear combinations held $50.2 \%$ of the total variance and yielded 0.686 for the Kaiser-Meyer-Olkin (KMO) criteria, which alone reflect a low level of sample adequacy. However, Bartlett's Test of Sphericity refused the hypothesis of no common variance at a 95\% confidence level. The scatter plot derived from the 2 first components revealed a greater proximity (1) among reasons that do not show an intention to keep using this transportation mode, such as "I do not have a car", "It's my only alternative" and "I do not have a driver's license", and (2) between the ones that favour system attributes (e.g. comfort, frequency, price and speed), traffic conditions and environmental awareness.

The high number of answers within the former group (1) indicates a concerning future, once current users are more likely to migrate to individual modes given a shift in their personal financial status (Kutzbach, 2009). In addition, as system attributes are the least chosen, behavioral intentions are probably low toward the system, since comfort and convenience factors are strong predictors of loyalty to public transportation modes (TRB, 2013). 
Pearson Product-Moment Matrix revealed a slight correlation between traffic conditions and system speed $(r=0.37, p<0.01)$, and not being able to use the car and the lack of parking spaces $(\mathrm{r}=0.27, \mathrm{p}<0.01)$. Regarding the first correlation, it supports that Curitiba' extensive exclusive bus lanes, which have a positive effect in decreasing travel time ratio during peak hours, are appreciated by users. The second correlation might indicate that reducing parking spaces within the city will be an effective measure to decrease car ridership within chosen areas.

\subsection{Satisfaction at Attribute and Overall Levels}

Satisfaction was evaluated through a 5-point Likert scale in a 17-question survey. The descriptive analysis shows fare (1.62), safety and security (2.17), and crowding conditions (2.30) having the worst results. Skewness values reflected that for the first 10 attributes, the left tail is longer in the distribution curve, therefore indicating higher dissatisfaction, as presented in Table 1. On the other hand, for overall satisfaction the distribution is approximatively even.

Table 1 - Descriptive analysis for system attributes and overall satisfaction

\begin{tabular}{|c|c|c|c|c|c|c|c|}
\hline & \multirow{2}{*}{$\begin{array}{c}\mathbf{N} \\
\text { Statistic }\end{array}$} & \multirow{2}{*}{$\begin{array}{c}\text { Attribute } \\
\text { Code }\end{array}$} & \multicolumn{2}{|c|}{ Satisfaction Results } & \multirow{2}{*}{$\begin{array}{c}\text { Std. Deviation } \\
\text { Statistic }\end{array}$} & \multicolumn{2}{|c|}{ Skewness } \\
\hline & & & Mean & Std. Error & & Statistic & Std. Error \\
\hline Fare & 544 & [SAT]_16 & 1.62 & 0.04 & 0.82 & 1.381 & 0.105 \\
\hline Safety and Security & 544 & [SAT]_07 & 2.17 & 0.04 & 1.03 & 0.555 & 0.105 \\
\hline Crowding Conditions & 544 & [SAT]_11 & 2.30 & 0.04 & 0.98 & 0.342 & 0.105 \\
\hline Vehicle Interior Conditions & 544 & [SAT]_10 & 2.37 & 0.04 & 1.02 & 0.438 & 0.105 \\
\hline Transit Connectivity & 544 & [SAT]_05 & 2.45 & 0.05 & 1.06 & 0.191 & 0.105 \\
\hline Service Frequency & 544 & [SAT]_02 & 2.56 & 0.05 & 1.08 & 0.269 & 0.105 \\
\hline $\begin{array}{l}\text { Application of Sustainable } \\
\text { Technologies }\end{array}$ & 544 & [SAT]_17 & 2.59 & 0.04 & 1.01 & 0.119 & 0.105 \\
\hline Bus Stop Infrastructure & 544 & [SAT]_12 & 2.62 & 0.04 & 0.98 & 0.106 & 0.105 \\
\hline Fleet Conservation & 544 & [SAT]_09 & 2.69 & 0.04 & 1.03 & 0.156 & 0.105 \\
\hline Travel Time & 544 & [SAT]_04 & 2.75 & 0.05 & 1.13 & 0.020 & 0.105 \\
\hline Road Conservation & 544 & [SAT]_14 & 2.82 & 0.04 & 0.98 & -0.079 & 0.105 \\
\hline Reliability & 544 & [SAT]_03 & 3.03 & 0.05 & 1.08 & -0.203 & 0.105 \\
\hline Information Service & 544 & [SAT]_13 & 3.07 & 0.05 & 1.20 & -0.161 & 0.105 \\
\hline Accessibility & 544 & [SAT]_01 & 3.22 & 0.05 & 1.08 & -0.422 & 0.105 \\
\hline Staff Behavior & 544 & [SAT]_08 & 3.37 & 0.04 & 0.91 & -0.342 & 0.105 \\
\hline Exclusive Bus Lanes Availability & 544 & [SAT]_15 & 3.45 & 0.04 & 1.04 & -0.401 & 0.105 \\
\hline Fare Integration & 544 & [SAT]_06 & 3.58 & 0.05 & 1.24 & -0.586 & 0.105 \\
\hline Overall Satisfaction & 544 & [SAT]_SY & 2.75 & 0.02 & 0.54 & 0.004 & 0.209 \\
\hline
\end{tabular}

The data set was put through an item reliability test, which returned 0.828 for the Cronbach's alpha test and, therefore, can be considered a reliable set of variables. Given this result, a Factor Analysis was performed using the Principal Components method, varimax rotation, standardized values and minimum eigenvalue set to cut at one. The result explained $48.9 \%$ of the variance and provided 0.869 for the KMO test (good sample adequacy), refused the noncorrelation hypothesis through Bartlett's Test of Sphericity at 95\% confidence level, and yielded 4 factors:

- Comfort: Fleet Conditions, Vehicle Interior Conditions, Bus Stop Infrastructure, and Road Conditions; [Cronbach's alpha - 0.716]

- Service: Service Frequency, Reliability, Travel Time, and Information Service; [Cronbach's alpha - 0.680]

- Integration: Accessibility, Transit and Fare Connectivity; [Cronbach's alpha - 0.548]

- Critical Attributes: Crowding Conditions and Fare. [Cronbach's alpha - 0.355] 
Safety and security, staff behavior, exclusive bus lanes availability, and application of sustainable technologies were excluded from the analysis, due to its loading factors $(<0.5)$. Furthermore, as Integration and Critical Attributes have low values for Cronbach's alpha, they can not be considered as reliable factors.

A Discriminant Analysis was performed between satisfaction variables and several descriptive ones. Women were found to be, on average, $6 \%$ less satisfied with the system than men, which is a reflex of the lower rates this group gave for fare $(-12.1 \%)$, bus stops infrastructure $(-12 \%)$, accessibility $(-11.1 \%)$, safety and security $(-10.4 \%)$ and vehicle interior conditions and crowding conditions (-10.3\%). This might be because women, in this sample, are more dependent on public transport than men, therefore facing more overcrowding conditions $(+11 \%)$ and being more likely to be robbed or to see a robbery in the system (+8\%). As a result, they have chosen more frequently the reasons that do not show an intention to keep using this mode.

Dependency, in general, was found to be a reducer of satisfaction. In the sample, those who use public transport more frequently showed lower satisfaction rates. For example, the group who use it three times a day is $9 \%$ less satisfied than people who use it twice a day. Overall satisfaction levels also decreased among people using the system more times a week and for more trip purposes. Moreover, these users usually ride feeder lines more often, which serve areas further away from the structural axis and have lower service frequency. As a result, safety and security, transit connectivity, fare, bus stop infrastructure, accessibility and travel time scores were affected.

Negative Social Safety Experiences (NSSE's) also had an adverse impact on the overall satisfaction $(-5.2 \%)$. Individuals that have seen a robbery or have been robbed granted lower results for safety and security $(-31.7 \%)$, fare $(-12.4 \%)$, service frequency $(-9.2 \%)$, travel time ($8.2 \%)$ and bus stop infrastructure (-6.3\%). A correlation between safety and security and bus stop infrastructure $(\mathrm{r}=0.335, \mathrm{p}<0.01)$ was found and could be a strategy to improve security perception. Overcrowding conditions had similar impacts. Users who reported facing crowded buses daily showed lower overall satisfaction scores $(-5 \%)$ for crowding conditions $(-19 \%)$, vehicle interior conditions (-15\%), service frequency $(-15 \%)$ and fare $(-14 \%)$.

On the other hand, the group that use public transportation due to traffic conditions perceives travel time $(+24.9 \%)$, fare $(+18.5 \%)$, service frequency $(+12.6 \%)$, accessibility $(+12.1 \%)$ and exclusive bus lanes $(+10.5 \%)$ much better than other groups. However, the ones who use it because they do not have a car or for being the only alternative granted lower results for fare, service frequency, accessibility, travel time and crowding conditions. These results, therefore, strengthens the idea that the construction of positive behaviors and mindsets toward public transportation could have promising results.

\subsection{Relative Importance through Descriptive Analysis}

Evaluating service attributes importance through Descriptive Analysis is the most used procedure to investigate relative importance. In this research, respondents were asked to rate the same 17 variables in a psychometric scale (extremely unimportant to extremely important). As anticipated, mean values were much higher than the ones found for satisfaction. Customers leaned toward scoring nearly all attributes at the top scales, hence making it difficult to differentiate them. Nonetheless, item reliability test resulted in 0.894 for the Cronbach's alpha 
test, thus indicating a consistent set of variables, even though there was only up to $5 \%$ difference between two subsequent attribute scores.

Safety and security (4.67), fare (4.61), fare integration (4.54), reliability (4.54), service frequency (4.53) and accessibility (4.30) appeared among the most important attributes (Table 2). Application of sustainable technologies (3.87) and staff behavior (3.77) were among the lowlevel importance attributes. Surprisingly, transit connectivity (3.64) and crowding conditions (3.60) also appeared among this category. The first six factors were correlated to Overall Satisfaction through Multiple Linear Regression Analysis (Ordinary Least Squares). The $\mathrm{R}^{2}$ was of $76.83 \%$, which indicates how much variance these attributes can explain at a 95\% confidence level.

Table 2 - Relative importance results through descriptive analysis

\begin{tabular}{|c|c|c|c|c|c|c|c|}
\hline & \multirow{2}{*}{$\frac{\mathbf{N}}{\text { Statistic }}$} & \multirow{2}{*}{$\begin{array}{c}\text { Attribute } \\
\text { Code }\end{array}$} & \multicolumn{2}{|c|}{ Mean } & \multirow{2}{*}{$\begin{array}{c}\text { Std. Deviation } \\
\text { Statistic }\end{array}$} & \multicolumn{2}{|c|}{ Skewness } \\
\hline & & & Statistic & Std. Error & & Statistic & Std. Error \\
\hline Safety and Security & 544 & [IMP]_07 & 4.67 & 0.03 & 0.72 & -2.682 & 0.105 \\
\hline Fare & 544 & [IMP]_16 & 4.61 & 0.04 & 0.83 & -2.687 & 0.105 \\
\hline Fare Integration & 544 & [IMP]_06 & 4.54 & 0.03 & 0.78 & -1.999 & 0.105 \\
\hline Reliability & 544 & [IMP]_03 & 4.54 & 0.03 & 0.75 & -1.923 & 0.105 \\
\hline Service Frequency & 544 & [IMP]_02 & 4.53 & 0.03 & 0.73 & -1.861 & 0.105 \\
\hline Accessibility & 544 & [IMP]_01 & 4.30 & 0.03 & 0.80 & -1.238 & 0.105 \\
\hline Travel Time & 544 & [IMP]_04 & 4.28 & 0.04 & 0.82 & -1.089 & 0.105 \\
\hline Information Service & 544 & [IMP]_13 & 4.24 & 0.04 & 0.87 & -1.183 & 0.105 \\
\hline Vehicle Interior Conditions & 544 & [IMP]_10 & 4.19 & 0.04 & 0.87 & -1.041 & 0.105 \\
\hline Fleet Conservation & 544 & [IMP]_09 & 4.13 & 0.04 & 0.86 & -0.804 & 0.105 \\
\hline Bus Stop Infrastructure & 544 & [IMP]_12 & 4.11 & 0.04 & 0.86 & -0.911 & 0.105 \\
\hline Road Conservation & 544 & [IMP]_14 & 4.10 & 0.04 & 0.86 & -0.775 & 0.105 \\
\hline Exclusive Bus Lanes Availability & 544 & [IMP]_15 & 3.98 & 0.04 & 0.93 & -0.832 & 0.105 \\
\hline $\begin{array}{l}\text { Application of Sustainable } \\
\text { Technologies }\end{array}$ & 544 & [IMP]_17 & 3.87 & 0.05 & 1.09 & -0.846 & 0.105 \\
\hline Staff Behavior & 544 & [IMP]_08 & 3.77 & 0.04 & 0.93 & -0.553 & 0.105 \\
\hline Transit Connectivity & 544 & [IMP]_05 & 3.64 & 0.05 & 1.14 & -0.436 & 0.105 \\
\hline Crowding Conditions & 544 & [IMP]_11 & 3.60 & 0.04 & 1.04 & -0.331 & 0.105 \\
\hline Mean Importance & 544 & [IMP]_SY & 4.18 & 0.02 & 0.54 & 4.460 & 0.209 \\
\hline
\end{tabular}

A Factor Analysis was performed following the same principles as the previous one. This was possible since all collected data was at the same scale and because the Cronbach's alpha results were extremely positive (0.894). The Factor Analysis aimed at explaining underlying patterns of data correlation through the reduction in the number of components. The data set produced 0.926 for the KMO test (great sample adequacy) refusing the non-correlation hypothesis through Bartlett's Test of Sphericity at 95\% confidence level. The two derived factors explained $47.1 \%$ of variance and were related to Comfort and Accessibility and System Performance, as presented below:

- Comfort and Accessibility: Fleet Conditions, Staff Behavior, Road Conditions, Bus Stop Infrastructure, Application of Sustainable Technologies, Vehicle Interior Conditions, Exclusive Bus Lanes Availability, Transit Connectivity, and Accessibility; [Cronbach's alpha - 0.849]

- Service Performance: Service Frequency, Fare, Reliability, Safety and Security, Travel Time, and Service Information. [Cronbach's alpha - 0.818]

This set of factors is much more reliable than the one found before, due to its higher level of consistency. System Performance is related in a wider level to service characteristics and it 
reflects the most relevant factors found in this Stated Importance procedure. Comfort and Accessibility is a combination of supplementary and convenience features. Crowding conditions and fare connectivity were excluded from the analysis due to low factor loadings $(<0.5)$.

The correlations between each variable and the Overall Satisfaction were further investigated through Model Regression Analysis. Service frequency (43.5\%), bus stop infrastructure (41.2\%), accessibility (37.9\%), fleet conservation (35.5\%), vehicle interior conditions (31.1\%) showed the greater $\mathrm{R}^{2}$ values, thus indicating the importance of investments on Comfort and Accessibility attributes as to retain and increase ridership among the studied group.

Discriminant Analysis showed that Service Performance attributes usually do not vary in importance among the analysed descriptive variables. Nevertheless, results from Comfort and Accessibility features differ given variations on perceived satisfaction. For example, women are more sensitive to crowding conditions $(+14 \%)$ and accessibility $(+7 \%)$; the lower income group values transit connectivity $(+10 \%)$, bus stop infrastructure, road conditions and exclusive bus lane availability (+8\%); the ones who use the bus for several trip purposes value accessibility $(+10 \%)$, transit connectivity ( $+9 \%)$, travel time and fleet conservation $(+9 \%)$; the ones who use it several times a day highly regard transit connectivity, crowding conditions ( $+8 \%)$, accessibility and fleet conservation ( $+6 \%)$. All these attributes were the ones which had lower satisfaction rates for each group, therefore that is probably what makes them more noticeable and, by consequence, more important.

Also, users who face more overcrowding conditions value better crowding conditions $(+16 \%)$, vehicle interior conditions $(+9 \%)$ and fleet conservation $(+7 \%)$. Users who have seen a robbery or have been robbed in the system attribute a relatively higher value to safety and security ( $+3 \%)$. This value may seem a low increase, but it is an attribute that have not shown any variation for any other descriptive variable. Furthermore, the group that use public transportation due to traffic conditions were less troubled with crowding $(-6 \%)$ and more concerned with exclusive bus lane availability $(+7 \%)$ and transit connectivity $(+5 \%)$. On the other hand, the ones that use the bus for the reasons of not having a car or for being the only alternative give more weight to crowding conditions.

Given the results, once Service Performance attributes are well stablished, public authorities and operation companies might want to focus on developing better crowding conditions and improving transit connectivity and fleet infrastructure as to retain and increase ridership among undergraduate students.

\subsection{GAP Analysis: Expected vs. Perceived Service}

Service quality is believed to be perceived along a spectrum ranging from ideal to unacceptable quality, in which a customer position depends on the nature of the existing gap between expected service and how the delivered service is perceived. Consequently, when expectations are higher than what is delivered, perceived quality tend to the lower side of the satisfaction range (Parasuraman, Zeithaml and Berry, 1985). Therefore, it is important for public authorities and service providers to understand the needs of public transportation users. By understanding these needs, services perceived as of high quality can be delivered, influencing positive wordof-mouth and increasing ridership. This knowledge is also an asset for developing effective policies and marketing campaigns. 
It was found a 52.4\% mean difference between mean Overall Satisfaction and mean Overall Importance (Table 3). The 17-variable data set for both criteria was also put through a Canonical Correlation Analysis, which yielded $45.3 \%$ for the first eigenvalue, thus indicating the existence of a GAP between expected and perceived services among the studied group. Furthermore, since importance values are higher, satisfaction tends to be perceived on the lower side of the spectrum. Therefore, once the most chosen reasons for usage does not favour loyalty toward public transportation and 58.8\% of the attributes have a broader dissatisfied distribution, undergraduate students are not likely to keep adopting this modal.

Table 3 - Expected v. Perceived Quality of Service GAP

\begin{tabular}{|c|c|c|c|c|c|c|c|}
\hline & \multirow{2}{*}{$\begin{array}{c}\text { Attribute } \\
\text { Code } \\
\end{array}$} & \multicolumn{2}{|c|}{ Satisfaction Mean } & \multicolumn{2}{|c|}{ Importance } & \multicolumn{2}{|c|}{ GAP } \\
\hline & & Statistic & Std. Error & Statistic & Std. Error & Difference & $\%$ \\
\hline Fare & [GAP]_16 & 1.62 & 0.04 & 4.61 & 0.03 & 3.00 & $185 \%$ \\
\hline Safety and Security & [GAP]_07 & 2.17 & 0.04 & 4.67 & 0.04 & 2.50 & $115 \%$ \\
\hline Service Frequency & [GAP]_02 & 2.56 & 0.05 & 4.53 & 0.03 & 1.97 & $77 \%$ \\
\hline Vehicle Interior Conditions & [GAP]_10 & 2.37 & 0.04 & 4.19 & 0.03 & 1.82 & $77 \%$ \\
\hline Travel Time & [GAP]_04 & 2.75 & 0.05 & 4.28 & 0.04 & 1.53 & $56 \%$ \\
\hline Reliability & [GAP]_03 & 3.03 & 0.05 & 4.54 & 0.04 & 1.52 & $50 \%$ \\
\hline Bus Stop Infrastructure & {$[\mathrm{GAP}]$-12 } & 2.62 & 0.04 & 4.11 & 0.04 & 1.49 & $57 \%$ \\
\hline Fleet Conservation & [GAP]_09 & 2.69 & 0.04 & 4.13 & 0.04 & 1.43 & $53 \%$ \\
\hline Crowding Conditions & {$[\mathrm{GAP}]$ 11 } & 2.30 & 0.04 & 3.60 & 0.03 & 1.29 & $56 \%$ \\
\hline $\begin{array}{l}\text { Application of Sustainable } \\
\text { Technologies }\end{array}$ & [GAP]_17 & 2.59 & 0.04 & 3.87 & 0.04 & 1.28 & $50 \%$ \\
\hline Road Conservation & [GAP]_14 & 2.82 & 0.04 & 4.10 & 0.04 & 1.27 & $45 \%$ \\
\hline Transit Connectivity & [GAP]_05 & 2.45 & 0.05 & 3.64 & 0.03 & 1.19 & $49 \%$ \\
\hline Information Service & {$[\mathrm{GAP}]$ 13 } & 3.07 & 0.05 & 4.24 & 0.04 & 1.17 & $38 \%$ \\
\hline Accessibility & [GAP]_01 & 3.22 & 0.05 & 4.30 & 0.05 & 1.08 & $34 \%$ \\
\hline Fare Integration & [GAP]_06 & 3.58 & 0.05 & 4.54 & 0.04 & 0.96 & $27 \%$ \\
\hline Exclusive Bus Lanes Availability & {$[\mathrm{GAP}] \_15$} & 3.45 & 0.04 & 3.98 & 0.05 & 0.54 & $16 \%$ \\
\hline Staff Behavior & [GAP]_08 & 3.37 & 0.04 & 3.77 & 0.04 & 0.40 & $12 \%$ \\
\hline Overall & [GAP]_SY & 2.75 & 0.02 & 4.18 & 0.02 & 1.44 & $52 \%$ \\
\hline
\end{tabular}

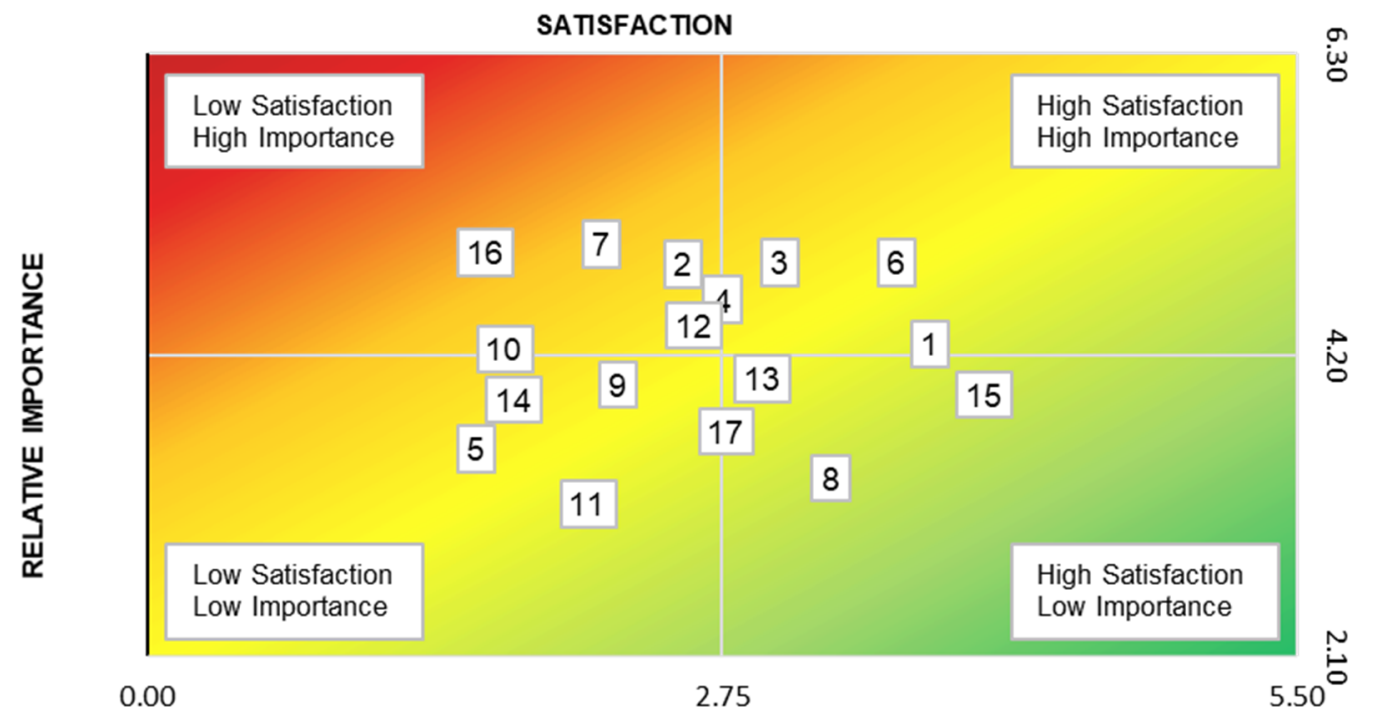

Figura 1. Quadrant Chart Matrix: Attribute Satisfaction-Attribute Relative Importance GAP

At the attribute level, the expected - perceived gap was assessed by the difference between mean satisfaction and importance results. By comparing, satisfaction and relative importance scores, the attributes are put into perspective. It enables the transit analyst to perceive easily 
which attributes are more critical and will have more impact on the public perception if improved. For this sample, the most pronounced difference was found for fare (3.00) and safety and security (2.50). These attributes are characterised by low satisfaction and high importance, therefore more effort should be put into improving them, as depicted in the Quadrant Chart Matrix from Figure 1.

Through Multiple Linear Regression Analysis, it was found that the first 7 attributes could hold $81.1 \%$ of sample variance. In comparison, through the relative importance results alone it was needed 8 factors to explain the same amount. Thus, this analysis aids to better select where to invest and market improvements as to create a positive sphere around public transport according to local needs.

\section{CONCLUSION}

Cities are bound by financial and geographical constraints and, therefore, continuous increase in road capacity is an unfeasible solution to accommodate current trends on car ownership. In this way, promotion of public transport is necessary as to reduce economic, social, and environmental impacts of extreme car dependency, such as unsustainable congestion volumes, increasing traffic accident rates, health-related issues, and overall quality of life.

We investigated the tendency for continuous public transportation adoption among undergraduate students from Curitiba. In this sense, the results indicate that under the current conditions the analysed group is likely to perform a mode switch towards individual modes. For instance, "I do not have a car", "It's my only alternative", and "I do not have a driver's license" were among the most common reasons for using public transport, while service and comfort aspects of the service were significantly less favored. Thus, suggesting negative behavioral intentions and attitudes towards public transport.

The analysis of satisfaction provides further evidence to this claim. 58.8\% of the attributes have a broader dissatisfied distribution from which Fare, Safety and Security, and Crowding Conditions exhibited the worst results. Additionally, those who are more dependent on public transport, thus using the system more times a day, more times a week or for more purposes, were found to display worst overall satisfaction results, which can be attributed to reduced satisfaction with Safety and Security, Transit Connectivity, Fare, Bus Stop Infrastructure, Accessibility, and Travel Time. On the same note, Negative Social Safety Experiences and facing overcrowding conditions often were also found to have a negative effect on overall satisfaction, while using the system due to traffic conditions was found to have positive influence on it. Therefore, creating an environment that reduces negative experiences are paramount to creating positive attitudes and, thus, retaining and increasing ridership.

On the same note, the analysis of relative importance revealed that respondents were likely to place more importance on the attributes that they perceived less satisfaction. Thus, highlighting the importance of creating an environment with reduced negative experiences as they are likely to become salient. For example, among those more dependent on public transport, Transit Connectivity, Crowding Conditions, Fleet Conservation, and Accessibility were shown to have more importance than for those less dependent on this travel mode. Overall, Safety and Security, Fare, Fare Connectivity, Fare Integration, Reliability, Service Frequency, and Accessibility were found to be the most important.

Finally, by comparing satisfaction and relative importance data through GAP analysis we yielded interesting results, such as evidencing a smaller number of attributes that are more 
likely to improve user intention towards public transport given their current levels of satisfaction and importance. Fare and Safety and Security are found to be the most critical attributes, suggesting that more effort should be put into their improvement as to retain and prospect more users. Additionally, Comfort and Accessibility attributes should be improved, once they have a strong influence on satisfaction as shown by the Model Regression Analysis. Consequently, public policies targeting reducing fares and overcrowding conditions and improving safety and security and the bus fleet infrastructure are necessary.

Moreover, a mindset shift in planning for urban infrastructure is needed as to endorse more sustainable development. The literature provides a range of acknowledged options towards decrease car ownership and increase the use of public transportation. However, the success of any measure depends on understanding the trends, the context and the expectations the population, in question has for a better quality of life.

\section{REFERENCES}

Abenoza, R. F.; O. Cats e Y. O. Susilo (2017) “Travel satisfaction with public transport: Determinants, user classes, regional disparities and their evolution," Transportation Research Part A: Policy and Practice, v. 95, p. 64-84. DOI: 10.1016/j.tra.2016.11.011.

Aksoy, S.; E. Atilgan e S. Akinci (2003) "Airline services marketing by domestic and foreign firms: Differences from the customers' viewpoint," Journal of Air Transport Management, v. 9, n. 6, p. 343-351. DOI: 10.1016/S0969-6997(03)00034-6.

Bartlett, J. E.; J. W. Kotrlik e C. C. Higgins (2001) “Organizational research: Determining appropriate sample size in survey research," Information Technology, Learning, and Performance Journal, v. 19. DOI: 10.1109/LPT.2009.2020494.

Bordagaray, M; L. Dell'Olio; A. Ibeas e P. Cecín (2014) “Modelling user perception of bus transit quality considering user and service heterogeneity," Transportmetrica A: Transport Science, v. 10, n. 8, p. 705-721. DOI: $10.1080 / 23249935.2013 .823579$.

Carrillat, F. A.; F. Jaramillo e J. P. Mulki (2007) "The validity of the SERVQUAL and SERVPERF scales: A meta-analytic view of 17 years of research across five continents," International Journal of Service Industry Management, v. 18, n. 5, p. 472-490. DOI: $10.1108 / 09564230710826250$.

Del Castillo, J. M. e F. G. Benitez (2013) “Determining a public transport satisfaction index from user surveys," Transportmetrica A: Transport Science, v. 9, n. 8, p. 713-741. DOI: 10.1080/18128602.2011.654139.

Celik, E.; N. Aydin e A. T. Gumus (2014) "A multiattribute customer satisfaction evaluation approach for rail transit network: A real case study for Istanbul, Turkey," Transport Policy. Elsevier, v. 36, p. 283-293. DOI: 10.1016/j.tranpol.2014.09.005.

Dell’Olio, L.; A. Ibeas e P. Cecín (2010) “Modelling user perception of bus transit quality,” Transport Policy, v. 17, n. 6, p. 388397. DOI: $10.1016 /$ j.tranpol.2010.04.006.

Dell'Olio, L.; A. Ibeas and P. Cecin (2011) "The quality of service desired by public transport users," Transport Policy. Elsevier, v. 18, n. 1, p. 217-227. DOI: 10.1016/j.tranpol.2010.08.005.

Doll, C. N. H. e J. A. P. Oliveira (2017) Urbanization and climate co-benefits: Implementation of win-win interventions in cities, Urbanization and Climate Co-Benefits: Implementation of Win-Win Interventions in Cities (1a ed.). Routeledge - Taylor \& Francis Group, New York, NY, USA. DOI: 10.4324/9781315667300.

Duarte, F.; T. Gadda; C. A. M. Luna e F. T. Souza (2016) "What to expect from the future leaders of Bogotá and Curitiba in terms of public transport: Opinions and practices among university students," v. 38, p. 7-21. DOI: 10.1016/j.trf.2015.12.013.

Eboli, L. e G. Mazzulla (2008) “Willingness-to-pay of public transport users for improvement in service quality," European Transport, v. 38, p. 107-118.

Ercan, T.; N. C. Onat; O. Tatari e J. D. Mathias. (2017) “Public transportation adoption requires a paradigm shift in urban development structure," Journal of Cleaner Production, v. 142, p. 1789-1799. DOI: 10.1016/j.jclepro.2016.11.109.

Figler, S. A.; P. S. Seiraj; E. W. Welch e N. Yavuz (2011) “Customer Loyalty and Chicago, Illinois, Transit Authority Buses,” Transportation Research Record: Journal of the Transportation Research Board, v. 2216, p. 148-156. DOI: $10.3141 / 2216-16$.

Filipović, S.; S. Tica; P. Zivanovic e B. Milovanovic (2009) “Comparative analysis of the basic features of the expected and perceived quality of mass passenger public transport service in Belgrade," Transport, v. 24, n. 4, p. 265-273. DOI: 10.3846/1648-4142.2009.24.265-273.

Friman, M.; L. Larhult e T. Gärling (2013) "An analysis of soft transport policy measures implemented in Sweden to reduce private car use," Transportation, v. 40, n. 1, p. 109-129. DOI: 10.1007/s11116-012-9412-y.

Fu, X. e Z. Juan (2017) "Exploring the psychosocial factors associated with public transportation usage and examining the 'gendered' difference," Transportation Research Part A: Policy and Practice, v. 103, p. 70-82. DOI: $10.1016 /$ j.tra.2017.05.017. 
Gössling, S. (2013) “Urban transport transitions: Copenhagen, city of cyclists,” Journal of Transport Geography. Elsevier Ltd, v. 33, p. 196-206. DOI: 10.1016/j.jtrangeo.2013.10.013.

Guirao, B.; A. García-Pastor e M. E. López-Lambas (2016) "The importance of service quality attributes in public transportation: Narrowing the gap between scientific research and practitioners' needs," Transport Policy. Elsevier, v. 49, p. 68-77. DOI: 10.1016/j.tranpol.2016.04.003.

Gurrutxaga, I.; M. Iturrate; U. Oses e H. Garcia (2017) "Analysis of the modal choice of transport at the case of university: Case of University of the Basque Country of San," Transportation Research Part A, v. 105, p. 233-244. DOI: 10.1016/j.tra.2017.04.003.

Javid, M. A.; T. Okamura; F. Nakamura; S. Tanaka e R. Wang (2016) “People’ s Behavioral Intentions Towards Public Transport in Lahore: Role of Situational Constraints, Mobility Restrictions and Incentives," v. 20, p. 401-410. DOI: $10.1007 / \mathrm{s} 12205-015-1123-4$.

Kutzbach, M. J. (2009) "Motorization in developing countries: Causes, consequences, and effectiveness of policy options," Journal of Urban Economics, v. 65, n. 2, p. 154-166. DOI: 10.1016/j.jue.2008.10.002.

Lai, W. e C. Chen (2011) "Behavioral intentions of public transit passengers - The roles of service quality, perceived value, satisfaction and involvement," Transport Policy. Elsevier, v. 18, n. 2, p. 318-325. DOI: 10.1016/j.tranpol.2010.09.003.

Litman, T. (1999) "Exploring the paradigm shifts needed to reconcile transportation and sustainability objectives," Transportation Research Record: Journal of the Transportation Research Board, v. 1670, n. 99, p. 8-12. DOI: $10.3141 / 1670-02$.

Machado-León, J. L.; R. de Oña e J. de Oña (2016) “The role of involvement in regards to public transit riders' perceptions of the service," Transport Policy, v. 48, p. 34-44. DOI: 10.1016/j.tranpol.2016.02.014.

Mahmoud, M. e J. Hine (2016) "Measuring the influence of bus service quality on the perception of users," Transportation Planning and Technology, v. 39, n. 3, p. 284-299. DOI: 10.1080/03081060.2016.1142224.

Morton, C.; B. Caulfield e J. Anable (2016) "Customer perceptions of quality of service in public transport: Evidence for bus transit in Scotland," Case Studies on Transport Policy. World Conference on Transport Research Society, v. 4, n. 3, p. 199207. DOI: 10.1016/j.cstp.2016.03.002.

Möser, G. e S. Bamberg (2008) "The effectiveness of soft transport policy measures: A critical assessment and meta-analysis of empirical evidence," Journal of Environmental Psychology, v. 28, n. 1, p. 10-26. DOI: 10.1016/j.jenvp.2007.09.001.

Mouwen, A. (2015) "Drivers of customer satisfaction with public transport services," Transportation Research Part A: Policy and Practice, v. 78, p. 1-20. DOI: 10.1016/j.tra.2015.05.005.

NTU (2017) Anuário NTU: 2016-2017. Associação Nacional de Empresas de Transporte Urbanos, Brasília. Available at: http://www.ntu.org.br/novo/upload/Publicacao/Pub636391736883773822.pdf. [In Portuguese]

De Oña, J.; R. de Oña; L. Eboli e G. Mazzulla (2013) "Perceived service quality in bus transit service: A structural equation approach," Transport Policy, v. 29, p. 219-226. DOI: 10.1016/j.tranpol.2013.07.001.

De Oña, J.; R. de Oña; C. Forciniti e G. Mazzulla (2016) "Transit passengers' behavioural intentions: the influence of service quality and customer satisfaction," Transportmetrica A: Transport Science, v. 12, n. 5, p. 385-412. DOI: $10.1080 / 23249935.2016 .1146365$.

De Oña, R. e de Oña, J. (2015) “Analysis of transit quality of service through segmentation and classification tree techniques," Transportmetrica A: Transport Science, v. 11, n. 5, p. 365-387. DOI: 10.1080/23249935.2014.1003111.

Onat, N. C.; M. Kucukvar; O. Tatari e Q. P. Zheng (2016) "Combined application of multi-criteria optimization and life-cycle sustainability assessment for optimal distribution of alternative passenger cars in U.S.," Journal of Cleaner Production, $v$ 112, p. 291-307. DOI: 10.1016/j.jclepro.2015.09.021.

Parasuraman, A.; V. Zeithaml e L. Berry (1988) "A Multiple Item Scale for Measuring Consumer Perceptions of Service Quality," Journal of Retailing, v. 64, n. 1, p. 12-37. DOI: 10.1016/S0148-2963(99)00084-3.

Parasuraman, A.; V. Zeithaml e L. Berry (1985) “A Conceptual Model of Service Quality and Its Implications for Future Research,” The Journal of Marketing, v. 49, n. 4, p. 41-50. DOI: 10.1016/S0148-2963(99)00084-3.

Rojo, M.; L. dell'Ollio; H. Gonzalo-Orden e A. Ibeas (2013) “Interurban bus service quality from the users' viewpoint,” Transportation Planning and Technology, v. 36, n. 7, p. 599-616. DOI: 10.1080/03081060.2013.845432.

TRB (2013) Transit Capacity and Quality of Service Manual. Transportation Research Board. DOI: 10.17226/24766.

Tyrinopoulos, Y. e C. Antoniou (2008) “Public transit user satisfaction: Variability and policy implications," Transport Policy, v. 15, n. 4, p. 260-272. DOI: 10.1016/j.tranpol.2008.06.002.

Van Lierop, D. e A. El-Geneidy (2016) "Enjoying loyalty: The relationship between service quality, customer satisfaction, and behavioral intentions in public transit," Research in Transportation Economics, v. 59, n. 1, p. 50-59. DOI: $10.1016 /$ j.retrec.2016.04.001.

Van, H. T.; K. Choocharukul e S. Fujii (2014) "The effect of attitudes toward cars and public transportation on behavioral intention in commuting mode choice - A comparison across six Asian countries," Transportation Research Part A, v. 69, p. 36-44. DOI: 10.1016/j.tra.2014.08.008.

Wang, S. M.; C. M. Feng e C. H. Hsieh (2010) "Stakeholder perspective on urban transport system service quality," Total Quality Management \& Business Excellence, v. 21, n. 11, p. 1103-1119. DOI: 10.1080/14783363.2010.529329.

Widianti, T.; S. Sumaedi; I. G. Mahatma; Y. Bakti; T. Rakhmawati e N. J. Astrini (2015) "Factors influencing the behavioral intention of public transport passengers," International Journal of Quality \& Reliability Management, v. 32, n. 7, p. 666692. DOI: 10.1108/IJQRM-01-2013-0002. 
Xia, T.; Y. Zhang; A. Braunack-Mayer e S. Crabb (2017) "Public attitudes toward encouraging sustainable transportation: An Australian case study," International Journal of Sustainable Transportation, v. 11, n. 8, p. 593-601. DOI: 10.1080/15568318.2017.1287316.

Yaya, L. H. P.; M. F. Fortià; C. S. Canals e F. Marimon (2015) "Service quality assessment of public transport and the implication role of demographic characteristics," Public Transport, v. 7, n. 3, p. 409-428. DOI: 10.1007/s12469-014-0099-7.

Zeithaml, V. A.; L. L. Berry e A. Parasuraman (1996) “The Behavioral Consequences of Service Quality," Journal of Marketing, v. 60, n. 2, p. 31-46. DOI: 10.2307/1251929.

Zitrický, V.; J. Gašparík e L. Pečený (2015) “The methodology of rating quality standards in the regional passenger transport,” Transport Problems, v. 10, p. 59-72. DOI: 10.21307/tp-2015-062. 